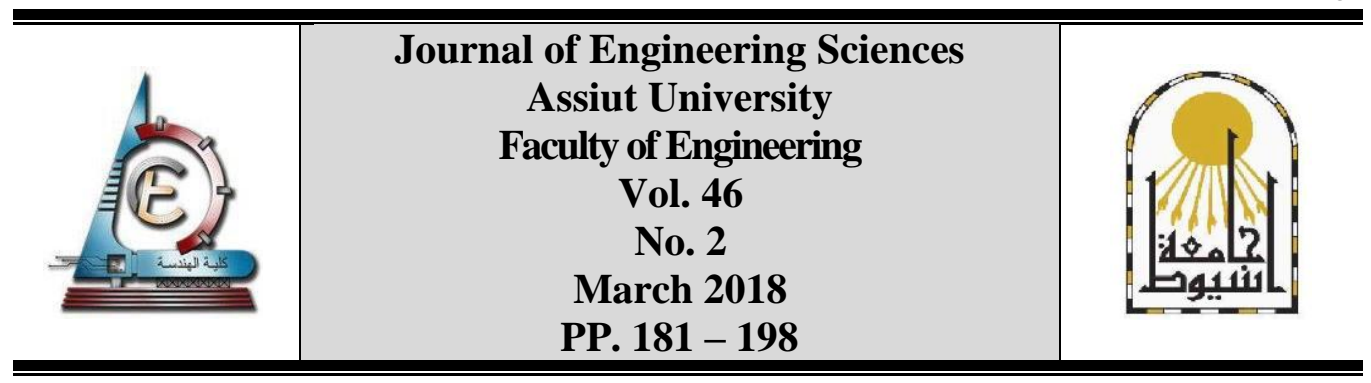

\title{
TITANIUM ENVELOPE: TOWARDS ICONIC PROJECTS TO CHANGE THE IMAGE OF KUWAIT CITY SHEIKH JABER ALAHMAD CULTURAL CENTER
}

\author{
Ebtehal Galal EI Deen Mohamed
}

\author{
Architecture Department, Faculty of Engineering -Matarya, Helwan University
}

Received 27 November 2017; Accepted 4 January 2018

\begin{abstract}
Because of quick changes in technology and switching from local to a globalized world, countries and cities are compelled to compete for one another to become an attractive workplace, social and cultural traveller destination. This paper introduces a new iconic architectural project in Kuwait "Sheikh Jaber Al Ahmed Cultural Centre", which used Titanium for the first time in the Middle East as a building envelope. The paper deals with the material and how it was employed in the building to deliver a unique design. The project was required as a national demand to meet the needs of the citizens culturally and to change the visual image of Kuwait City as well. The work aims to tackle how successful the experiment is by Qualitative and Quantitative framework methods. Two well-documented topics: Titanium as a promising architectural material, and Sheikh Jaber Al Ahmed Cultural Centre design in Kuwait as a global iconic project have been discussed to cover the pros and cons of each, followed by an analysed questionnaire that measures the project role in enhancement of the visual image of Kuwait City In addition to the development of cultural life among Kuwait residents.The Conclusion and recommendations will be presented to support the impact of building iconic Titanium sculptural project to the city visual image.
\end{abstract}

Keywords: Titanium, Cultural Centre, Building Envelope, Visual Image.

\section{Introduction}

Previous studies showed that there are three methods for promoting cities:

- social and cultural mega ceremonies and events,

- restoration and promoting heritage

- and constructing iconic buildings and projects.

Accordingly, many cities have employed iconic building to be able to get attention. the main purpose of doing this is to build an identifiable visual image of the city [1]. City image is composed of all memories and visual images of places whether positive or negative, the extent to which a person can recognize or recall a place as being distinct from other places as defined by Kevin Lynch [2]. But recent visual image of Kuwait did not change for a long time as shown in Fig. (1). 


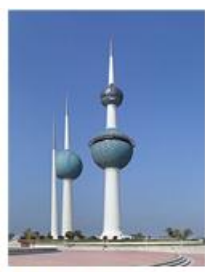

Kuwait

Towers 1979

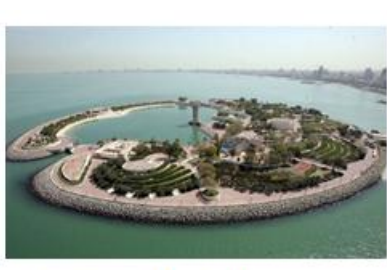

Green Island

1988

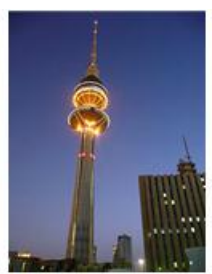

Kuwait

liberation

Tower 1991

Fig. 1. The traditional visual image of Kuwait [3].

In the last decades Glass, Aluminium and Stainless steel were the major architectural cladding materials in Kuwait for public and commercial projects, but as a new vision for Kuwait and as desire to compete for global projects appearance in Gulf region especially and worldwide in general, design and construct mega projects become one of the governmental and national missions, they started to emerge on the world architectural map with the new Kuwait International Airport that targets the LEED Gold. The project is designed to be the first terminal -for passengers- to obtain this level of environmental accreditation in the world, and it was designed by Foster and Partners in 2010 to be completed in 2020. [4].

Building iconic and global projects which carry messages above all other concerns, however, is still a demand, which led to design and construction of a unique Kuwaiti project Sheikh Jaber Al Ahmed Cultural Centre, to be the latest addition to Kuwait and the world architecture, through its unique geometric form and its Titanium envelope as well.

\subsection{Aims}

The research aims to evaluate and discuss the iconic project of Sheikh Jaber Cultural Centre from different views:

- The compatibility of selecting Titanium as building envelope for the project, regarding pros and cons of design aesthetics and material functions.

- The impact of constructing the new iconic cultural centre with its unique form and materials to add positive influence on the image of Kuwait City.

- The contribution of the project to the citizen's cultural life.

\subsection{Hypotheses}

Titanium is a high-cost architectural material in purchase; the paper assumes that using such expensive material will suit the project design purpose as the Member of Parliament (MP); Saleh Al-Mulla stated that the establishment of such Centre would contribute to the rise of Kuwait cultural leadership platforms again after a decline in the recent years [5].

The feasibility of using this material to the value of the building both architecturally and functionally is in question.

\subsection{The methodology}

In this paper, a Qualitative and Quantitative framework was adopted to tackle the architectural Titanium usage, benefits, considerations, and effect on the final new iconic 
Ebtehal Galal El Deen Mohamed, Titanium envelope: towards iconic projects to change the ...

project. Besides exploitation of the material to achieve the functional and aesthetic building requirements to develop the Kuwait City image.

\section{Materials and methods}

In this part, the paper will discuss tow domains separately through the descriptive, interpretive methods as shown in Fig. (2), both will lead to the analytical study which will take part later.
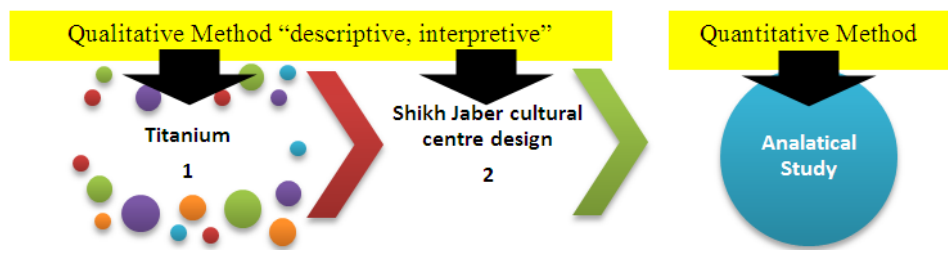

Fig. 2. The work structure [6].

\subsection{Titanium}

Ti or Titanium is a chemical element with shining silver look, with atomic number 22 . In 1791 Titanium was discovered in Britain, by William Gregor, and Martin Heinrich named it for the Greek mythology Titans [7]. Titanium is the ninth most numerous materials in the Earth's crust, but not found freely in nature instead it found in minerals such as Rutile ${ }^{1}$, Ilmenite ${ }^{2}$ [8].

Titanium took an extended period of maturation before start producing it industrially in 1948. Through research and development, this material has revealed infinite possibilities in many fields.

For architecture's applications Titanium appears to be relatively new in western, Middle East architecture, but it has been used on hundreds of buildings in Japan for over twenty-five years.

Since designing Guggenheim Museum by Frank Gehry, and after its opening in October 1997 Fig. (3), architectural Titanium continues to clad different projects around the world. Moreover, the Museum became the worldwide icon for architectural titanium applications [9].

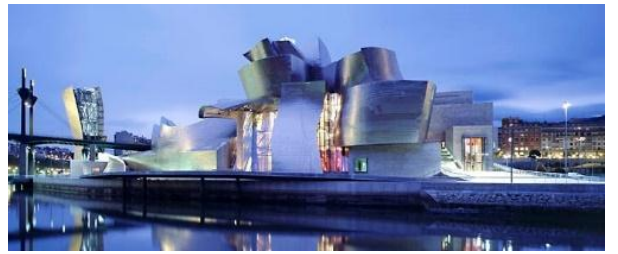

Fig. 3. The Guggenheim Museum, Spain, Frank Gerhry 1997 [10]

Many contemporary architectural projects were then covered with titanium because of its properties which encouraged architects to adopt it in their designs in a broad manner as shown in Fig. (4).
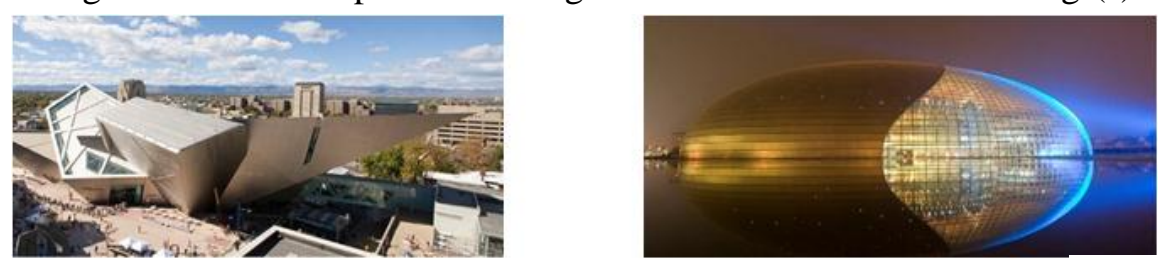

Fig. 4. A- Denver Art Museum, Colorado 2006 [11]. B- National Centre for Performing Arts, China 2007 [12].

\footnotetext{
${ }^{1}$ Titanium dioxide, $\mathrm{TiO}_{2}$.

${ }^{2}$ Iron titanium oxide $\mathrm{FeTiO}$, it is the most important ore of titanium.
} 


\subsubsection{Titanium characters}

In this part Table .1. Will present the physical features of the titanium and its benefits for architectural applications.

Table 1.

The properties of titanium and its benefits on projects [6].

\begin{tabular}{|l|l|l|} 
Titanium withstands acid rain, \\
marine environments, volcanic \\
ash residue, urban pollution, \\
industrial emissions and other \\
extremely aggressive \\
atmospheric conditions. \\
Titanium will not weather or \\
fade due to ultraviolet rays.
\end{tabular}

\begin{tabular}{ll|ll} 
Of all architectural metals, \\
titanium has the lowest \\
coefficient of thermal \\
expansion almost equal to \\
glass, concrete, brick and \\
stone.
\end{tabular} \mid $\begin{aligned} & \text { This allows designs that } \\
& \text { feature titanium and } \\
& \text { glass, concrete as the } \\
& \text { prominent architectural } \\
& \text { elements. }\end{aligned}$

\begin{tabular}{|c|c|c|c|c|}
\hline 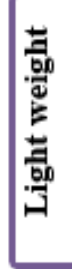 & 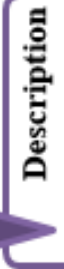 & $\begin{array}{l}\text { Titanium is lightweight } \\
\text { metal, it imposes less } \\
\text { loads on the structure and } \\
\text { can be fabricated using } \\
\text { traditional metal forming } \\
\text { methods. }\end{array}$ & 岂 & $\begin{array}{l}\text { It enables further weight } \\
\text { reduction through design, } \\
\text { which is a great for } \\
\text { structural design issues. } \\
\text { and permits ease of } \\
\text { installation. }\end{array}$ \\
\hline
\end{tabular}

\begin{tabular}{|c|c|c|c|}
\hline 嘉 & مًّ & $\begin{array}{l}\text { Titanium is equivalent in } \\
\text { strength to steel, and it } \\
\text { will flex during periods of } \\
\text { violent movement. }\end{array}$ & $\begin{array}{l}\text { Flixapility and strenght } \\
\text { make it suitable for the } \\
\text { Earthquake-prone } \\
\text { areas. }\end{array}$ \\
\hline
\end{tabular}

\begin{tabular}{|c|c|c|c|c|}
\hline 量 & 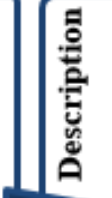 & $\begin{array}{l}\text { Titanium is an excellent } \\
\text { insulator. Its thermal } \\
\text { conductivity is very low } \\
\text { (1/10 of aluminium). }\end{array}$ & 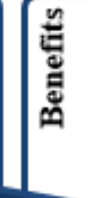 & $\begin{array}{l}\text { It increases a } \\
\text { building's energy } \\
\text { efficiency. and it will } \\
\text { suitable for hot areas. }\end{array}$ \\
\hline 量 & 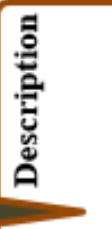 & $\begin{array}{l}\text { Titanium forming, welding } \\
\text { and bonding uses the same } \\
\text { tichniques used in ordinary } \\
\text { stainless steel }\end{array}$ & 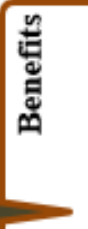 & $\begin{array}{l}\text { It means avilability of } \\
\text { expert workers who } \\
\text { worked with other } \\
\text { architetural metal with } \\
\text { no more cost. }\end{array}$ \\
\hline
\end{tabular}


Table 1. (Cont.)

\begin{tabular}{|c|c|c|c|c|}
\hline 迡 & 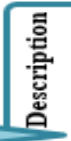 & $\begin{array}{l}\text { Titanium is biocompatible, } \\
\text { nontoxic material and able to } \\
\text { osseointegrate. }\end{array}$ & 岂 & $\begin{array}{l}\text { This feature will } \\
\text { suited to medical } \\
\text { usage. }\end{array}$ \\
\hline 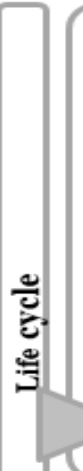 & & $\begin{array}{l}\text { When it used as exterior } \\
\text { cladding, the initial cost is } \\
\text { higher than other metals. } \\
\text { But fabrication and } \\
\text { installation prices will be } \\
\text { almost similar as for other } \\
\text { metals, it is only } 5 \% \text { to } \\
10 \% \text { more than stainless } \\
\text { steel. } \\
\text { Titanium's immunity to } \\
\text { corrosion eliminates the } \\
\text { need for repair and } \\
\text { continuous maintenance. }\end{array}$ & \multicolumn{2}{|c|}{$\begin{array}{l}\text { In total life cycle cost, } \\
\text { titanium has a clear } \\
\text { advantage over other } \\
\text { metals. it is highly } \\
\text { durable, recyclable } \\
\text { which reduces costs } \\
\text { involved in its } \\
\text { production. } \\
\text { It has a lower lifetime } \\
\text { cost that other metals } \\
\text { used in architecture and } \\
\text { construction. }\end{array}$} \\
\hline 总 & 흘 & $\begin{array}{l}\text { Architectural titanium could be } \\
\text { processed to achieve a variety of } \\
\text { surface textures, from a soft } \\
\text { matte to a near gleaming } \\
\text { reflectivity. } \\
\text { it also could be delvered in } \\
\text { diffrent coloures by using } \\
\text { Anodic oxidation. }\end{array}$ & 岁 & $\begin{array}{l}\text { These properties } \\
\text { enable the } \\
\text { material to be } \\
\text { suited for modern } \\
\text { and contemporary } \\
\text { designs. }\end{array}$ \\
\hline 掌 & 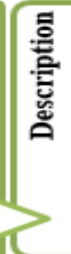 & $\begin{array}{l}\text { It is } 100 \% \text { renewable and } \\
\text { recyclable, does not degrade, and } \\
\text { as a result, does not contaminate } \\
\text { the environment. } \\
\text { it is the most inert metal and have } \\
\text { the longest life cycle of all } \\
\text { architectural metals. }\end{array}$ & & $\begin{array}{l}\text { Very suitable } \\
\text { for green } \\
\text { ตั } \\
\text { building } \\
\text { specification. }\end{array}$ \\
\hline
\end{tabular}

Beside the benefits there are many points must be considered when using titanium generally:

a) Titanium colouring

In most architectural cladding with titanium it is used in its natural silver finish, but sometimes other colours are required then the material could be exposed to Anodic oxidation, it is an electrochemical process to produce an oxide film (transparent and colourless) on a metallic surface [13].

The resulting colour can be seen of interference of light, ample colour spectrum range could be produced using different film thickness in a phenomenon called rainbow principle [14] as shown in Fig. (5 and 6).

Moreover, when colouring titanium is many points must consider:

- The surface conditions will influence the resulted colour because the film is too thin,

- Because the colour is a light interference result, the final colour may be varying from the designed according to time of the day, seasons, or wither conditions,

- Titanium get dirt like other materials, and this could lead to a colour change or even discoloured material, but it could be cleaned easily by using suitable detergent [15]. 


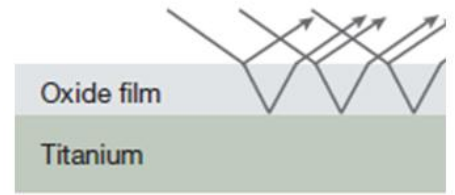

Fig. 5. The principle of interference colour [15]

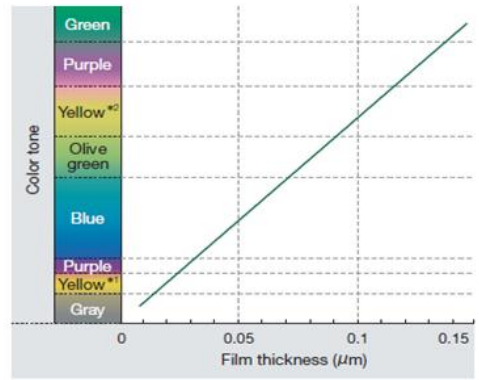

Fig. 6. The relation between film thickness and interference colour [15].

b) Titanium texturing

The soft finish of titanium could have different textures using many techniques like laser surface texturing Fig. (7).

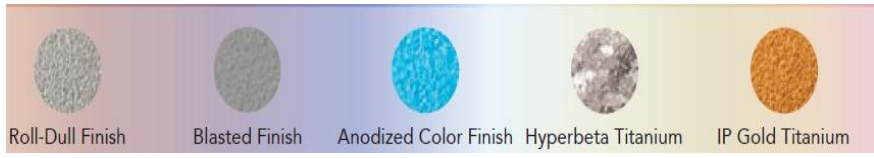

Fig. 7. Example of texturing [16]

\subsubsection{Titanium applications}

Titanium is a rich material with many privileges over other metals as discussed before; those features make it suits many applications as presented in Fig. (8).

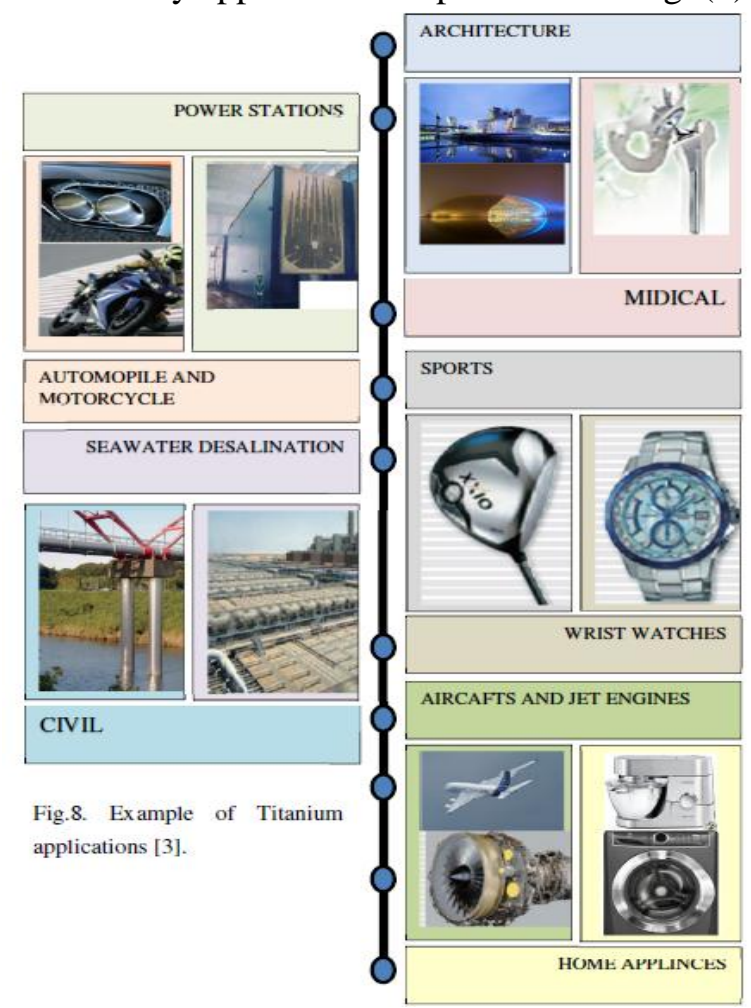




\subsection{Sheikh Jaber al Ahmad cultural centre}

Sheikh Jaber Cultural Centre is the latest opened mega project in Kuwait; it is under the umbrella of the National Council for Culture, Arts, and Literature, which replaces the Ministry of Culture. The new cultural district will attract the world's leading performers and be an endless source of civic pride for the people of Kuwait. Converting the visual image of Kuwait City into a brand image also will lead to improving marketing of the city image.

\subsubsection{Project introduction}

Sheikh Jaber Al-Ahmad Cultural Centre is one of the fastest-growing international engineering projects regarding design and implementation. The Public Building was opened in December 2016, and it cost 770-million Dollar Fig. (9). The project is being procured on a design and build basis for SSH firm, which is one of the leading firms in the Middle East and it took 22 months to be completed. The project needed about 10,000 workers to complete 14 million working hours to be finished [17]. The work is done under the patronage of the Amiri Diwan represented by the Engineering Department.

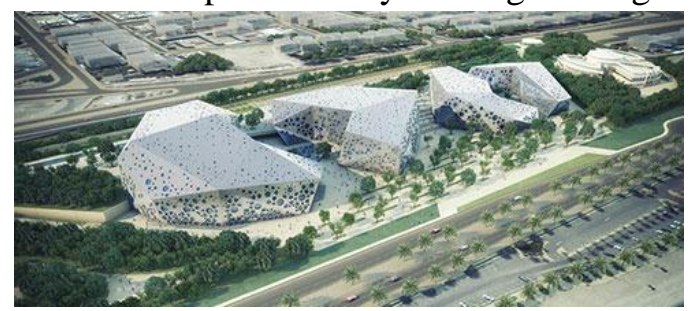

Fig. 9. Sheikh Jaber Al Ahmad Cultural Centre [18].

\subsubsection{Awards}

Sheikh Jaber Al Ahmad Cultural Centre has been awarded:

- The Mirt Award for Best Global Projects, awarded by the US architectural magazine Engineering News-Record (INR). The prize is awarded to the world's best projects, with challenges and risks both in design and construction in other countries.

- In July 2017, the centre won the International Property Awards (IPA) for the Best Engineering Project and the Best Interior Engineering Project in the Public Buildings category [19].

\subsubsection{Architectural details}

Area: the centre has taken a place in a land with total area of 210,000 square meters, the built area is about 110,000 square meters, there are gardens with an area of 100,000 square meters, and parking spaces of 3200 cars with Arabian Gulf View Fig. (10). [20].

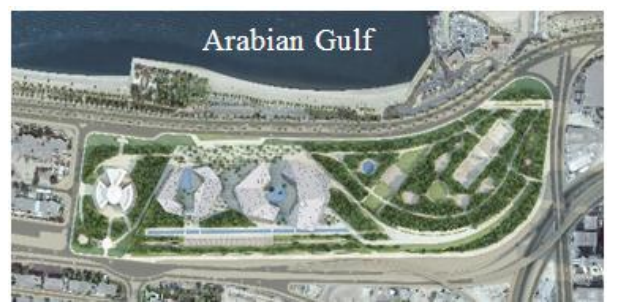

Fig. 10. An overhead view of the Theatres District [21]

Natural conditions: Kuwait's climate is quite severe, with substantial seasonal variations. 
Table 2.

The weather conditions in Kuwait during the year.

\begin{tabular}{|l|l|l|}
\hline Temperatures & Summer & Winter \\
\hline Dust storms & $\begin{array}{l}\text { Can exceed 55 with hot } \\
\text { winds, blowing dust. }\end{array}$ & $\begin{array}{l}\text { Can fall to } 0^{\circ} \mathrm{C} \text {, and sometimes } \\
\text { less. }\end{array}$ \\
\hline $\begin{array}{l}\text { Predominant } \\
\text { winds }\end{array}$ & $\begin{array}{l}\text { Occasional dust storms. It can last for many days or even weeks, } \\
\text { and at times they can reduce visibility to only a few meters. }\end{array}$ \\
$\begin{array}{l}\text { north-west. These winds are commonly known as the } \\
\text { 'Shamals' and carry a fine talc-like dust. Secondary winds } \\
\text { come from the south-east. }\end{array}$ \\
\hline
\end{tabular}

Regarding weather conditions, Public Buildings designed to be completely isolated from outside. Therefore, with the proximity to the Gulf shore, the choice of façade design, finishing materials and the shape of the openings is essential to achieve the internal comfort conditions for visitors, allowing for long periods of enjoyment despite climatic changes.

The program: the cultural centre includes four buildings Fig. (11). Moreover, they could be accessed from spacious entrance courtyards; they sit like jewels within the more massive public park [17]. The key buildings are:

- Theatre Centre and Opera House: This area comprises three main theatres, Theatre One being 2000 seats and Theatre Two 700 seats, theatre three 200 seats, with services areas.

- Music Centre: This area has a Concert Hall of 1000 seats, a Recital Hall, a rehearsal room, Musical Library, Children Musical Centre

Moreover, a music lecture theatre.

- Historical Document and Library Centre: This area has a library, archive/exhibition, administrative and financial departments, and three floors of offices, MPU, with the Presidents Suite on the top floor.

- Conference Centre: This area comprises a 500-seat cinema, a Symposium, lecture rooms and VIP area. [21].

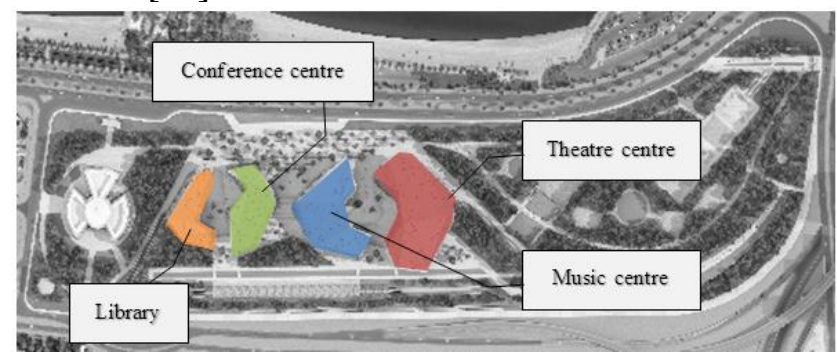

Fig. 11. The project layout and buildings functions [21]

The concept: Astronomy was a significant contribution of Arabs to the world; stars were used to navigate travelling through deserts and seas. From the importance of stars, it was a unique element for Islamic pattern design which used in building throughout the Islamic world. Muslims used geometry and mathematics as they distinguished in to develop patterns from a simple star to an intricate design pattern as shown in Fig. (12). 

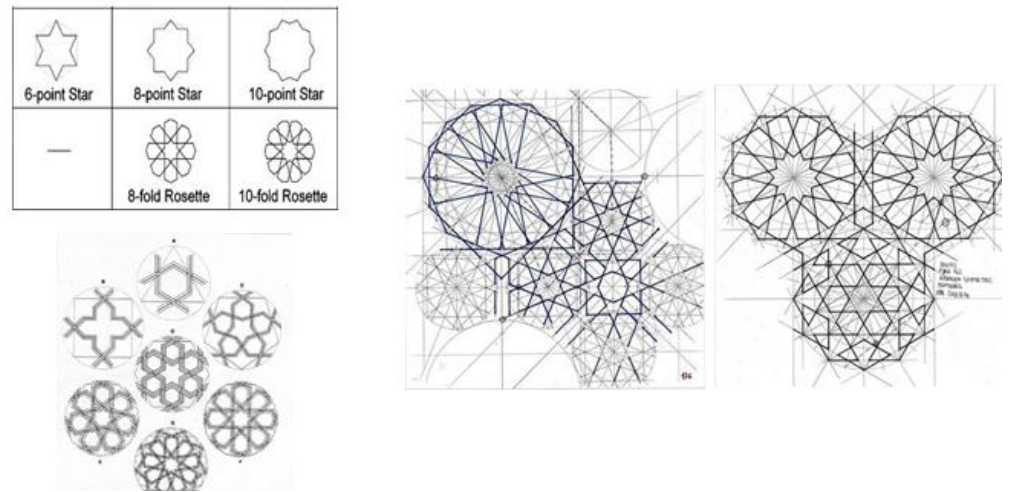

Fig. 12. Example of simple and complex stars patterns [22], [23], [24].

Each facade for each building got its design pattern depending on its shape and dimensions with a variety of solids and voids to create different effects Fig. (13).
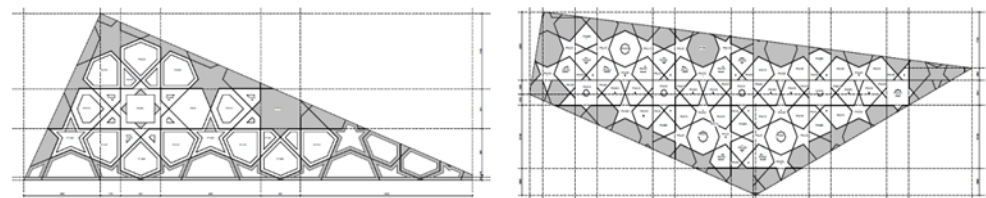

Fig. 13. Shows the variations of the employed pattern in the project's facades. [21]

\subsubsection{Construction details}

- The centre used more than 400 thousand cubic meters of concrete, which is enough to manufacture 14 towers such as the Liberation Tower in Kuwait which is $372 \mathrm{~m}$ Height.

- The intricate designs used about 25 thousand tons of iron, where it was adopted in the construction of buildings from abroad to create a free metal structure without any internal substrates and the external pillars on the dimensions of 70 meters and 45 meters high Fig. (14). [20].

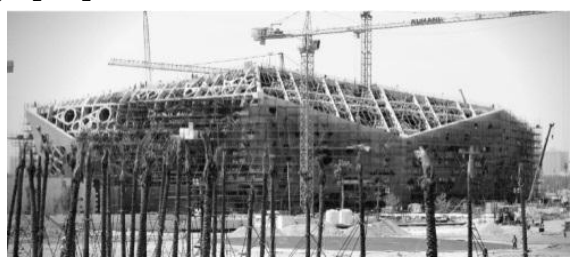

Fig. 14. The structural system for the outer skin [25]

- Titanium was used for the first time in the Middle East through the purchase of significant amount to cover the exterior - $(52,000$ square meters which are enough to make 30 small passengers plane)-, it costs almost $17 \%$ of the total budget which equals to 120 million Dollar. Because its advantages SSH have designed the Titanium cladding system to free span, envelope and protect the public spaces and functions beneath [20].

Architectural Titanium generally can be supplied in many shapes like a coil, sheet, composite panel, and tube. The sheet is the most commonly used form, with typical thicknesses from $0.4 \mathrm{~mm}$ to $1 \mathrm{~mm}$, available in widths up to $48^{\prime \prime} \mathrm{Fig}$. (15). Moreover, the project employed many forms of:

Titanium Alloy Strip, Sheet, Plate, Bars, Billets, Seamless Pipe, Welded Pipe, and Titanium Alloy Wire [14]. [21]. 
The plates have been purchased from United State as design requirements with small grooved lines to refract sun rays to avoid glare.

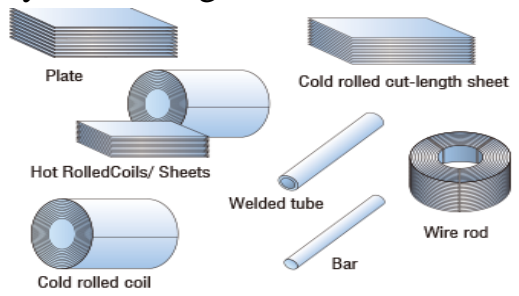

Fig. 15. Titanium manufactured forms. [26]

\subsection{The Analytical study}

After collecting the important information about the major topics, a designed questionnaire was distributed to measure the impact of the project on the citizen's cultural life, in addition to its effect on the city visual image. A sample of 100 of Kuwait's residents was asked to fill the form with a demographic variation between Kuwaitis, NonKuwaitis Arabs, Non-Kuwaitis non-Arabs as shown in Fig. (16).

We should keep in mind that Kuwait is a multi-ethnic country; the current population is approximately 4 million. Kuwaitis make up about $40 \%$ of the population; the remainder are foreign workers who make up the rest of the population, divided among non-Kuwaiti Arabs $25 \%$, and others 35\%. [27]

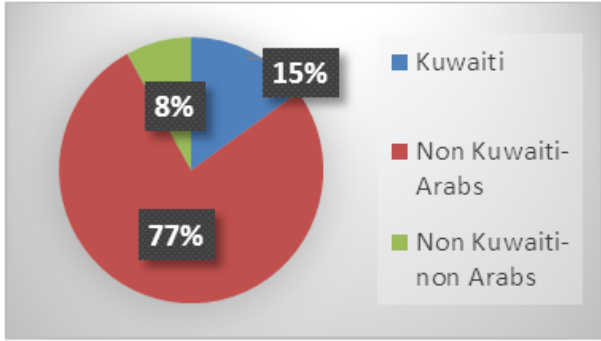

Fig. 16. Shows the percentage of Kuwaitis responses vs Non-Kuwaitis [6].

The form also covered a range ages between 20:50. Most of them were between 31:40 years $46 \%$, followed by the age group $41: 50$ with $25 \%$ as shown in Fig. (17). Moreover, the form covered a variety of specialities and professions to find out the effect of the project from different points of view according to work fields and interest as shown in Fig. (18).

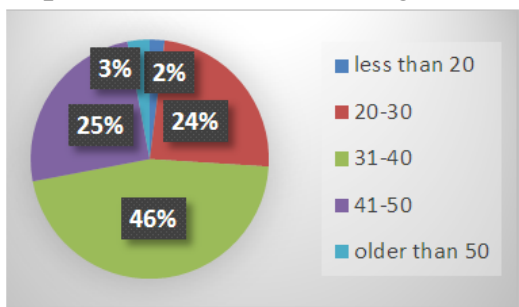

Fig. 17. The age groups. [6].

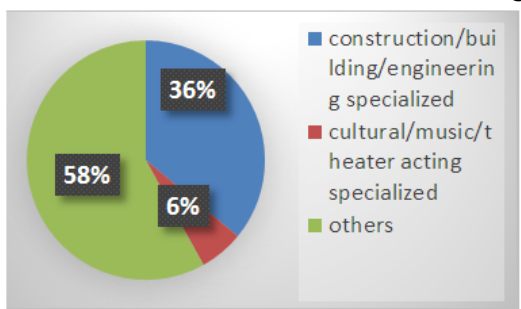

Fig. 18. The work field groups. [6].

Most of the respondents did not visit the project from inside just passed by, that percentage reached almost 57\% of the sample answers, as shown in Fig. (19), Poor advertising and the relatively high-ticket prices are the main reasons behind low attendance 
rate for cultural performances as shown in Fig. (20). Moreover, Citizens in Kuwait did not used to attend cultural, musical, opera, or international play; due to the lack of facilities that serve these shows to suit the population needs, only about three or four small theatres are available for local theatre performances around Kuwait. The project houses the first Opera and specialized music halls to host large and international shows in Kuwait.

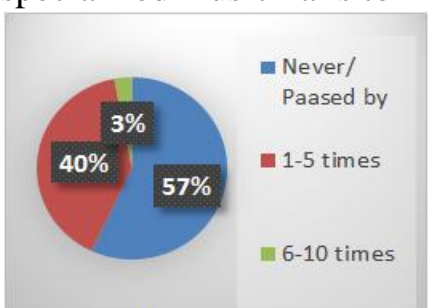

Fig. 19. The age groups. [6].

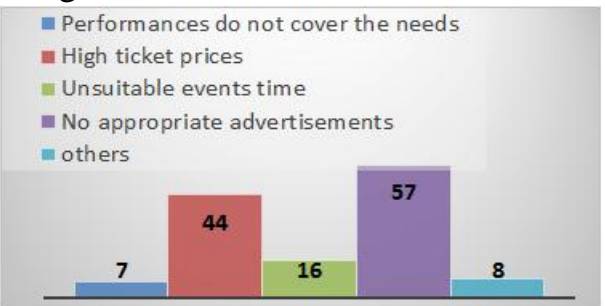

Fig. 20. The work field groups. [6].

The project is a multi-destination for all type of visitors, Parks and cafes attracted most users who showed that $50 \%$ of the visits were to stay in the open area facing the dancing fountain as they used to do in most outing in Kuwait. Instead, $11 \%$ attended Theatrical performances, $12 \%$ attended musical performances, and $2 \%$ only of the visits were to the library and the Conference Centre as shown in Fig. (21).

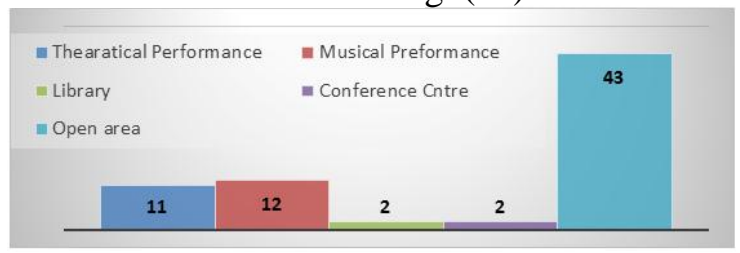

Fig. 21. The rate of visiting different spaces in the project. [6].

\section{Results and discussion}

The previous part discussed the overview and the main features of Titanium as a promising material in manufacture and architecture, also the new iconic Kuwaiti cultural centres that employed such material for the first time in the Middle East architecture followed by a survey to measure the project impact.

The unique project design with Titanium envelope has many aesthetics and attraction aspects, which encourage visitors to spend their time there, and made the project iconic in architecture world; such aspects could be divided into the following:

\section{A- Exterior:}

- The complex geometrical forms inspired by the Islamic architecture created the richly textured outer skin of each building, as shown in Fig. (22), which formed considerable public spaces around and below that benefited from the interaction of light and shadow. Covering external Titanium facades with irregular segments had a significant impact in adding the sparkling effect of the building remotely [17] [20].

- Titanium also kept the flame away from the interior when the project was on fire in February 2017 [29]. The design and materials used were optimally exploited in protecting the building as the Titanium cladding meant minimal damage, as shown in Fig. (23).

- The Monumental scale of the form which extends along by the Gulf Road attracts the drivers and visitors to discover the place, as shown in Fig. (24). 


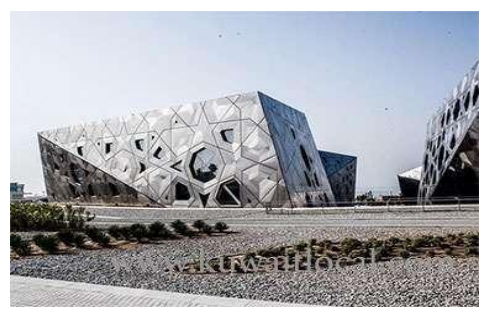

Fig. 22. The outer day view and reflection [28]

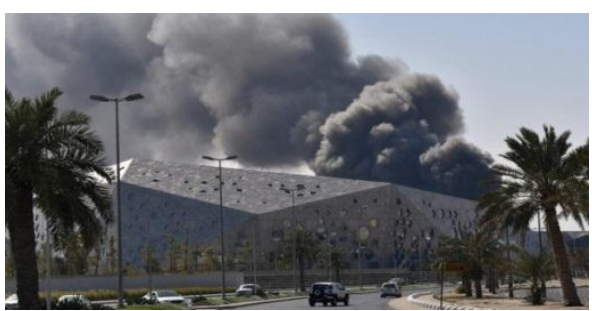

Fig. 23. The cultural centre fire on 6 Feb 2017
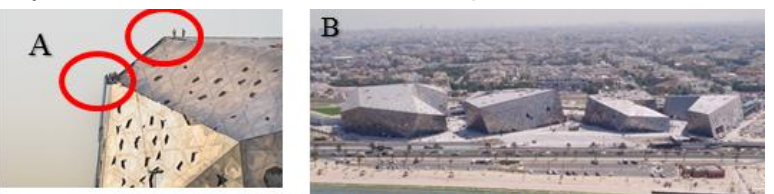

Fig. 24. The monumental scale

A- The scale of workers on the building roof [29].

B- The road, cars scale vs the project scale [31].

- The coloured lighted facades which appear at night are admirable, attracting eyes and they were designed by SSH engineers as shown in Fig. (25). To reduce energy consumption, LED units (RGB) are used in lighting.

- The dancing fountain of the Sheikh Jaber Al-Ahmad Cultural Centre is a new addition to the tourism in Kuwait, the charming view with its bright colours and beautiful formations is a destination that attracts visitors to the Centre [20], as shown in Fig. (26). The fountain is surrounded by many restaurants and cafés for serving visitors.

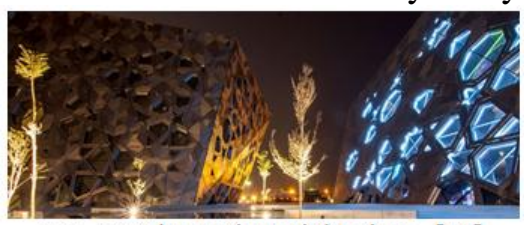

Fig. 25. The project night view [31].

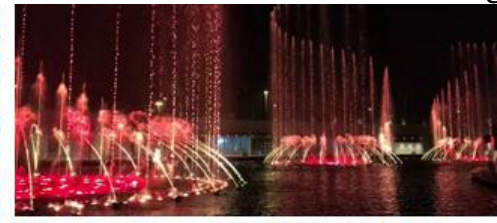

Fig. 26. The dancing fountain [32].

B- Interior

The project's interior is the source of luxury and beauty. There are world-class spaces, below the outer skin, which would exude a heightened sense of expectation as shown in Fig. (27).
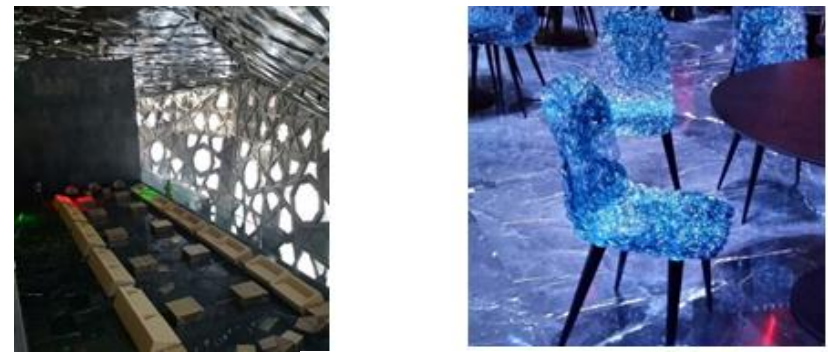

Fig. 27. The luxury of interior spaces [33] [34]

- The inner skin effect:

The cladding designed to blend light and shade; multiple blocks of refractors allow reflections of the sun from different openings according to the daylight hours [20]. 
Stainless Steel covered the steel frame from inside with waterproofed material as a middle layer between the stainless steel and Titanium Fig. (28).
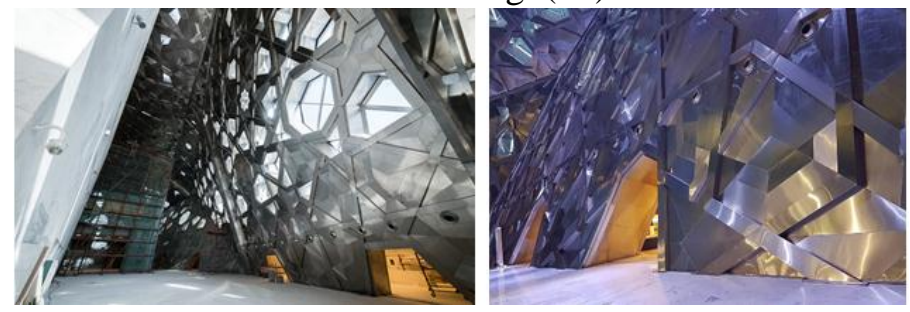

Fig. 28. The daylight effect and the Stainless Steel inner cover [18] [35]

C- The double skin:

The project is double skinned as shown in Fig. (29); the outer part which built as a dome with no inner support to enable free space consists of the steel structure and the Titanium cladding from outside and Stainless Steel from inside, and the inner part which built with the reinforced concrete.

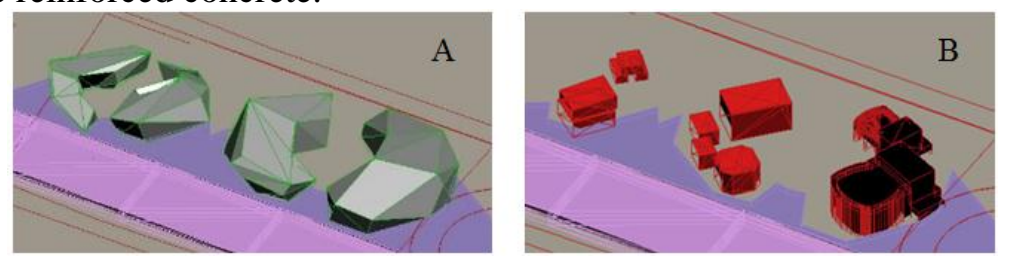

Fig. 29. Shows A- The outer steel and cladding skin, B-The inner mass form built with reinforced concrete [21].

Both envelop (the double skin) are essential to achieving acoustic insulation conditions for a project that combines a range of different buildings with different requirements Fig. (30). Including (Opera house, drama, and musical performance theatres) which needs prevention of the sound of musical performances from reaching the other side of the facades and vice versa, and the (Conference Centre as well as the documentary Library) which need to have entirely quite an atmosphere for carrying out their functions.

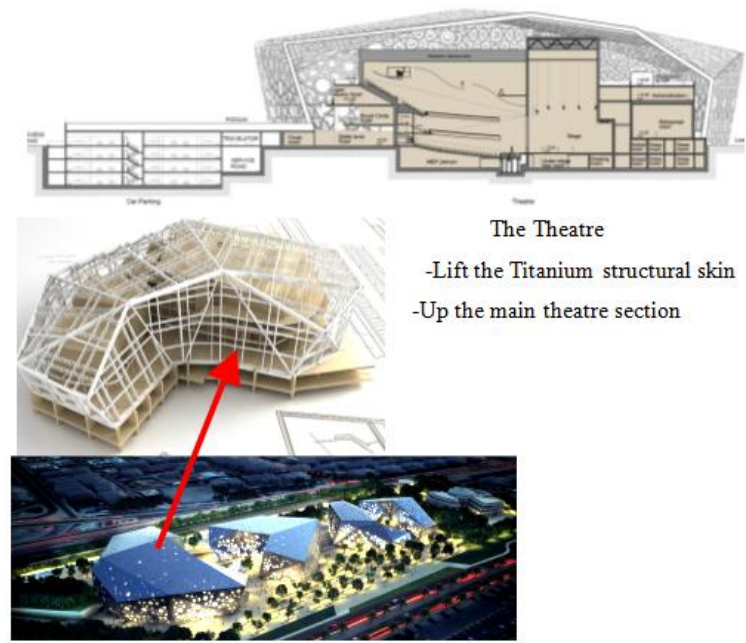

Fig. 30. Shows the project's double skin for two of its four buildings. [21]

We should consider the existence of the public gardens with different interests from the internal functions of the project. Thus, the use of double facades is an ideal solution to 
achieve the separation of functions and access to each of their own atmosphere. Moreover, such duplication is functional to achieve the optimal isolation from the different weather conditions for ensuring the personal comfort especially that the weather condition in Kuwait is quite severe as shown before in Table.2. Duplication also gives eyes spaciousness spaces to enjoy as shown in Fig. (31).
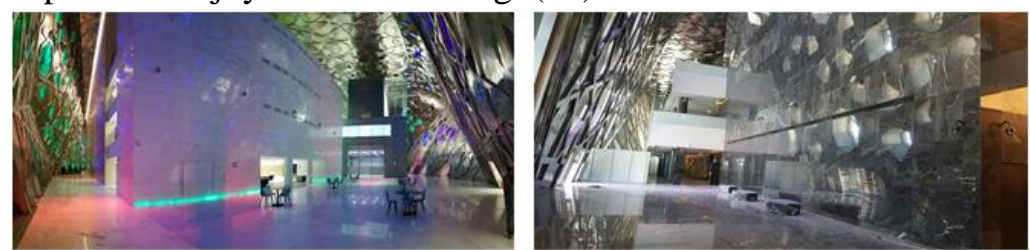

Fig. 31. The spacious interiors show the titanium dome with no internal columns and the reinforced concrete buildings inside. [33].

One objective of the questionnaire was to collect citizens views about the design, the selected unique iconic design form (4 jewels) were the most attracted attention items for the project which attracted the attention of $78 \%$ of sample, followed by choosing of the new shiny exterior finishing (Titanium) which attract $56 \%$ of visitor's attention, internal luxurious finishing and the project functions $27 \%$ for each as shown in Fig. (32).

Furthermore, the specialists in design and construction filed showed that the project design and form were the major attention point for them, which attract $52 \%$ of the field worker. Otherwise, the Titanium as the exterior finishing material got $12 \%$ of the attention! Fig. (33).

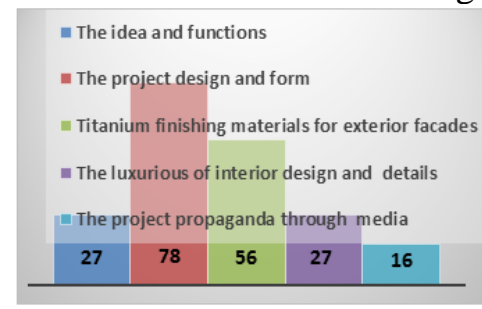

Fig. 32. Shows what attract visitors to the project [6]

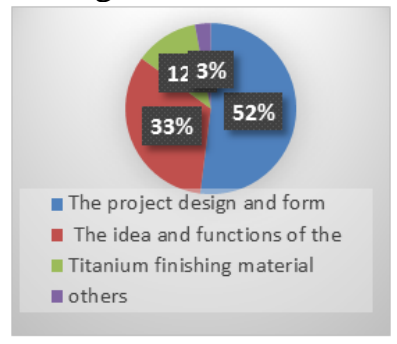

Fig. 33. Shows what attract (worker in design and construction filed) to the project [6].

Therefore, the responses showed that it was a major need to build this iconic mega cultural project to develop the cultural life of citizens, Moreover, to provide diverse regional and global cultural alternatives as well as local cultural performances. It was not only governmental demands but also national demand to meet citizen needs as $66 \%$ of the sample showed necessary needs to have such multi-purpose cultural projects as result of insufficiency of the existing old ones as shown in Fig. (34). The construction of the project and the importance of a specialized will equipped spaces will help in reviving the cultural life in Kuwait through the international and regional presentations and events hosted by the Centre as $76 \%$ of the sample admitted that as shown in Fig. (35).

The questionnaire also showed that $73 \%$ of the total sample admits the positive contribution of the project to change the image of Kuwait as a tourist and cultural destination as shown in Fig. (36). 
Moreover, the project reflects the lifestyle in Kuwait through the availability of facilities, services, and a high level of luxury. As a result, it could make the iconic project a famous Kuwaiti landmark just like Kuwait towers as $63 \%$ of the sample agreed with that possibility as shown in Fig. (37).

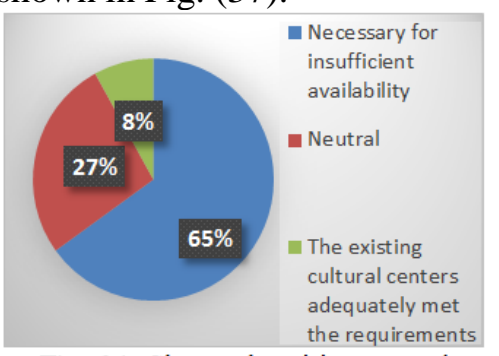

Fig. 34. Shows the citizens need to new multi-purpose cultural projects [6].

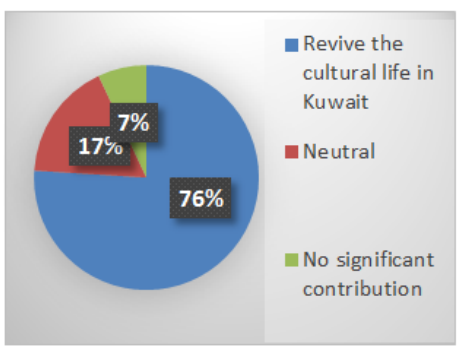

Fig. 35. The effect of the new iconic cultural project on the cultural life in Kuwait [6].

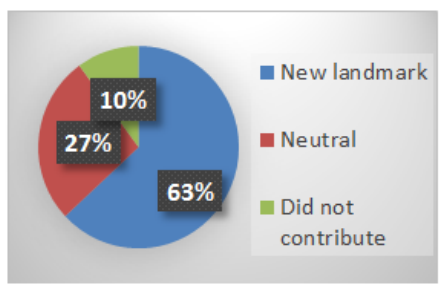

Fig. 37. Shows the views about new Kuwait landmark [6].

\section{Conclusion}

Titanium with its beautiful soft silver or textured colour finish could become the favourite metal used for architectural applications worldwide, just like the early stages of aluminium, only its economic feasibility of purchase is standing in the way of a broader use in architecture, but long-term savings from durability and low maintenance make titanium one of today's most cost-effective building materials on a lifecycle and sustainability basis.

Maximum utilization of all the advantages of Titanium has been employed in Sheikh Jaber Al-Ahmad Cultural Centre; the physical features of the material beside utilizing its aesthetics in exterior design. They succeed in designing the ultimate architecture requirements form and function for a long lifecycle, which makes it a positive addition to citizens to enrich the cultural life in Kuwait. Moreover, based on the analysis of the project, the iconic building effectively integrated to the context, successfully added a positive contribution to the image of Kuwait City which has not changed from a long time, to be able to market the city regionally and internationally to compete as a new traveller destination.

\section{REFERENCES}

[1] M. Riza , D. Naciye and M. Fasli, City Branding and Identity, 2012.

[2] A. Bayraktar and C. Uslay, Strategic Place Branding Methodologies and Theory for Tourist Attraction, USA: IGI Glopal, 2016, p. 91.

[3] Urban branding strategies and the emerging Arab cityscape, Saudi Arabia: Dar Al Hekma University, Saudi Arabia, 2008, p. 127.

[4] "Foster+Partners," [Online]. Available: https://www.fosterandpartners.com/projects/kuwait- 
international-airport/. [Accessed 11 2017].

[5] "Mullah for cultural centers in the provinces: a successful step from the Council of Ministers," Alrai, no. A0-11238, p. 8, 2010.

[6] Author, 2017.

[7] "Royal Society of Chemistry," [Online]. Available: http://www.rsc.org/periodictable/element/22/titanium. [Accessed 12 2017].

[8] "Titanium-Chemicool," [Online]. Available: https://www.chemicool.com/elements/titanium.html. [Accessed 10 2017].

[9] "VSMPO-AVISMA Corporation," [Online]. Available: http://www.vsmpo.ru/en/pages/Stroitelstvo. [Accessed 7 2017].

[10] "Architecturaltitanium," [Online]. Available: http://www.architecturaltitanium.com/projects/commercial/guggenheim/guggenheim.html. [Accessed 10 2017].

[11] "Architecturaltitanium," [Online]. Available: http://www.architecturaltitanium.com/projects/commercial/denver/denver.html. [Accessed 6 2017].

[12] JoeyWan and Arndalarm, "Twistedsifter," [Online]. Available: http://twistedsifter.com/2010/03/the-egg-building-beijing-china/. [Accessed 10 2017].

[13] "Corrosionpedia," [Online]. Available: https://www.corrosionpedia.com/definition/1471/anodic-oxidation. [Accessed 10 2017].

[14] "Azoma," [Online]. Available: https://www.azom.com/article.aspx?ArticleID=1299. [Accessed 6 2017].

[15] " NIPPON STEEL \& SUMITOMO METAL CORPORATION," [Online]. Available: http://www.nssmc.com/product/catalog_download/pdf/T003en.pdf. [Accessed 10 2017].

[16] " NIPPON STEEL \& SUMITOMO METAL CORPORATION," [Online]. Available: http://www.nssmc.com/en/product/titan/ . [Accessed 10 2017].

[17] "SSH," [Online]. Available: http://www.sshic.com/projects/sheikh-jaber-al-ahmadcultural-centre. [Accessed 9 2017].

[18] Mark, "Twofortyeight," [Online]. Available: http://248am.com/mark/kuwait/my-visit-tothe-sheikh-jaber-al-ahmad-cultural-centre/. [Accessed 6 2017].

[19] "KUNA," [Online]. Available: http://www.kuna.net.kw/ArticleDetails.aspx?id=2629464\&Language=ar. [Accessed 10 2017].

[20] "Kuwait News Agency," $2017 . \quad$ [Online]. Available: https://www.kuna.net.kw/ArticlePrintPage.aspx?id=2589060\&language=ar.

[21] "Sheikh Jaber Al Ahmad Cultural Centre, Tender documents," SSH consultant office, 2017, Kuwait.

[22] Y. Abdullahi and M. Rashid, Evolution of Islamic geometric patterns, Malysia: Sciencedirect, 2013, pp. 243-251.

[23] K. Critchlow, Islamic Patterns. An Analytical and Cosmological Approach, London: Thames and Hodson, 1976, p. 171.

[24] "Pinterest," [Online]. Available: https://pl.pinterest.com/pin/335940453432482609/?lp=true. [Accessed 10 2017].

[25] "SSH," [Online]. Available: http://www.sshic.com/. [Accessed 6 2017].

[26] " NIPPON STEEL \& SUMITOMO METAL CORPORATION," [Online]. Available: http://www.nssmc.com/en/product/titan/feature / . [Accessed 10 2017]. 
Ebtehal Galal El Deen Mohamed, Titanium envelope: towards iconic projects to change the ...

[27] Cultural Intelligence for Military Operations, Kuwait: FOUO Marine Corps Intelligence Activity, 2003, p. 2.

[28] "KuwaitLocal," [Online]. Available: https://www.kuwaitlocal.com/event/sheikh-jaber-alahmed-cultural-center-fireworks-show. [Accessed 12 2017].

[29] "Designmena," [Online]. Available: http://www.designmena.com/portfolio/in-pictures-sshdesigned-sheikh-jaber-al-ahmad-cultural-centre-in-kuwait. [Accessed 6 2017].

[30] A. IMANOVA, "Designmena," [Online]. Available: http://www.designmena.com/thoughts/ssh-designed-opera-house-catches-fire-in-kuwait. [Accessed 2511 2017].

[31] "Dirtymonitor," [Online]. Available: http://www.dirtymonitor.com/projects/sheikh-jaberal-ahmad-cultural-center. [Accessed 10 2017].

[32] [Online]. Available: https://i.ytimg.com/vi/J18iYkusOpM/maxresdefault.jpg. [Accessed 10 2017].

[33] SSH's Engineers, 2017.

[34] "instagram," [Online]. Available: https://www.instagram.com/. [Accessed 11 2017].

[35] "SSH," [Online]. Available: http://www.sshic.com/projects/sheikh-jaber-al-ahmadcultural-centre. [Accessed 6 2017]. 


\section{التيتانيوم كمادة تخليف: نحو مشاريع إيكونية}

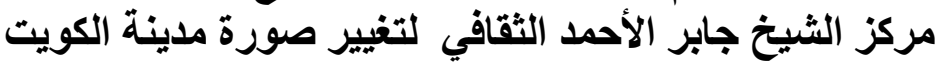

\section{الملخص العربى:}

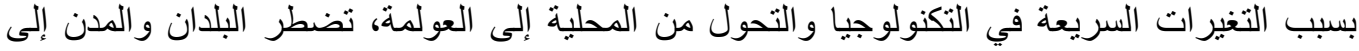

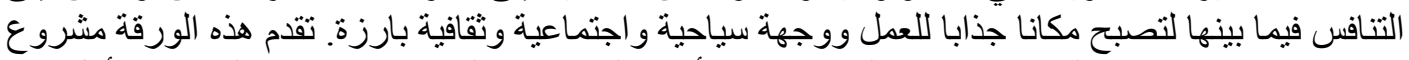

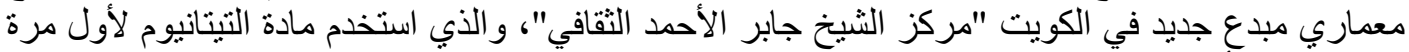

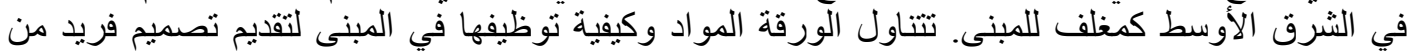

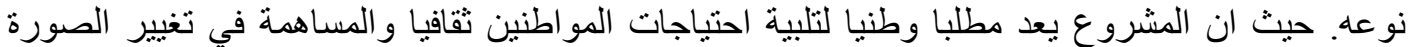

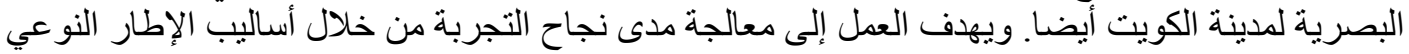

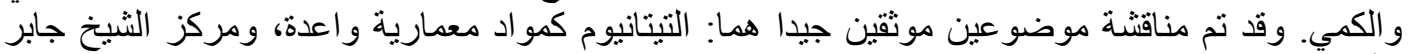

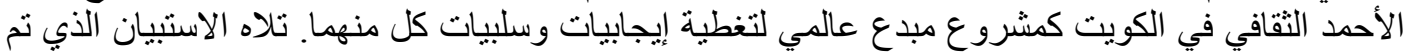

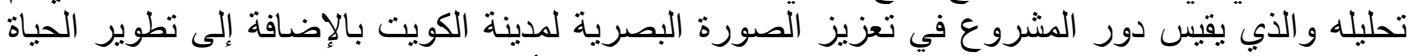

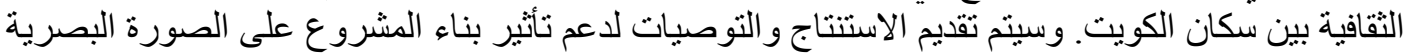

